\title{
Modelling and Methodology for Window Selection with Energy Efficiency Criteria in Chile
}

\author{
Ignacio Allende \\ Los Zarzales 1533, Santiago 9270842. Chile, \\ Ignacio.allende.|@hotmail.com
}

\begin{abstract}
This article presents the development of a methodology associated with the selection of windows with energy efficiency criteria in Chile. It provides the optimal option in a housing project, according to specific search parameters by region, commune, orientation, materiality, among others options. At the same time, it is possible to download the technical characteristics of the selected window instantly.
\end{abstract}

According to results obtained on the simulation, S2 showed better energy efficiency performance in the three cities studied (Antofagasta, Santiago and Concepcion). Mainly the transmittance value was slightly smaller than S1 solutions. In general, windows with lower thermal transmission (U) achieve better energy efficiency in homes. However, the selection of optimal windows for a project should always be based on the geographical area, the orientation of the facade or wall, the surface of the light, or the visibility to be projected (dimensions), and the thermal transmittance values $(U)$.

Keywords - Sustainability, Energy efficiency, Window, Thermal transmission, Transmittance values.

\section{INTRODUCTION}

Currently, Chile has joined multiple sustainable agreement and due to this, Chile actively participate such as a member of the Organization for Economic Cooperation and Development (OECD), Asia Pacific Economic Cooperation (APEC) and the United Nations Framework Convention on Climate Change (UNFCCC). Consequently, a series of national strategies is laid down, for the short and mediumterms, which seeks to favour the transition to a more sustainable and efficient country. [1] [2] [3]

For the development of these, the European reality was studied, which had a successful work program and extensive experience. One of the initiatives that stood out in this area was Directive 2010 / 31 / EU of the European Parliament [4], which is the basis for the energy rating of homes. It also defines the objectives and standards of energy efficiency in buildings by
2020.

Then, the study and analysis of the different energy sectors of Chile began, to know the state of the country in this matter and determine what the gap that exists with high-standard countries is.

In this regard, each the residential and the mining sectors represent $15 \%$ of the total national energy consumption. This indicates the magnitude of the context, taking and into account the importance of mining in Chile. [5] [6]

On the other hand, the National Energy Strategy 20122030 stipulates an Energy Efficiency Action Plan 20122020 that aims to achieve a $12 \%$ reduction in projected energy demand in the year 2020 [7] [8]. Additionally, national law No. 20,257 was also enacted, which states that non-conventional renewable energy sources must generate $10 \%$ of the energy by 2024 [9].

Notably, the residential sector has sustainable construction standards [10] [11] [12], according to the Handbook of Housing Energy Qualification [13] and the General Law of Urbanism and Constructions of Chile [14]. As a result, there is a need to innovate in this area, creating a methodology that allows selecting windows with energy efficiency criteria.

\section{METHODOLOGY}

\section{A. Study Areas}

Three research areas are involved in the study development, namely Laws and Standards, Market Research and Technical Characteristics. The investigative process is detailed in Fig. 1.

\section{Laws and Norms}

First, all information on national laws and regulations related to window selection was collected, as well as additional information, such as manuals and proposed standards - notably, the General Ordinance of Urban Planning and Construction [15]. 

http://dx.doi.org/10.21622/RESD.2020.06.1.008

On the other hand, the thermal zones of the cities of Chile, they were defined by maps proposed by MINVU [16]. Alternatively, the MINVU update on the communes that have the Air Decontamination Program was incorporated [17] [18]. Also, there is complementary information associated with sustainable construction standards [10] [11] [12] according to the Handbook of Housing Energy Qualification [13], and Climate Explorer [19].

After searching for the applicable legal and regulatory information, the parameters for the methodology were established and defined. Those parameters are necessary to generate an algorithm that allows simulations of different window configurations.

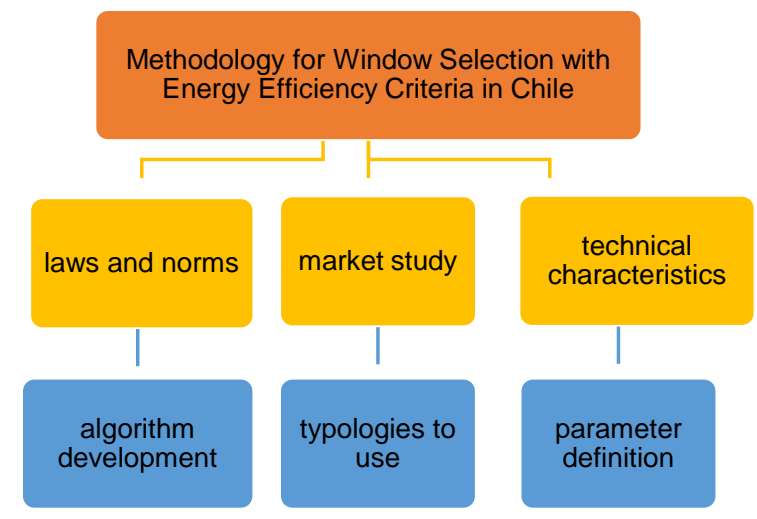

Fig .1 Flowchart to obtain the methodology for the selection of windows with energy efficiency.

\section{Market study}

At this point, the market window that includes recurring characterization patterns in different types of windows available. However, the windows present technical information and tests. These are fully available to be selected by the methodology database to ensure effectiveness during implementation. These involve the articles consulted from MINVU [20] [21], as well as suppliers [22]. Moreover, it includes a sample of twenty-eight windows, with all the relevant information.

Subsequently, the windows are added to the methodology and three types are defined; bringing down, sliding and projecting. Each of them has a subdivision according to the frame and thermal background.

Regarding the Chilean window market, it is correct to affirm that investments in the real estate sector have been in a constant growth throughout the years [23] [24] producing an increase in the demand for windows.
However, the products with the most significant presence in the market are Aluminium and PVC. The First is the most frequent for having a lower manufacturing cost, for the number of companies that distribute it and for its age in the market. On the other hand, PVC has only been gaining ground until recently, since public policies use it as a baseline for all their projects in order to generate energy savings in homes, lower maintenance costs, better acoustics [25]. The market distribution is represented by Fig. 2, that reflects an approximation of the growth of both over the years.

\begin{tabular}{|c|c|c|c|}
\hline \multirow{2}{*}{ Window Type } & \multicolumn{3}{|c|}{$\begin{array}{c}\text { Amount of money in the window } \\
\text { industry per year (M / USD) }\end{array}$} \\
\cline { 2 - 4 } & 2017 & 2018 & 2019 \\
\hline Aluminium & 120,5 & 126,5 & 131,5 \\
\hline PVC & 31,6 & 31,0 & 32,8 \\
\hline Total (M / USD) & 152,1 & 157,5 & 164,3 \\
\hline
\end{tabular}

Fig .2 Amount of money in the window industry per year.

\begin{tabular}{|l|c|c|}
\hline \multirow{2}{*}{\multicolumn{1}{|c|}{ Characteristics }} & \multicolumn{2}{c|}{ Window Type } \\
\cline { 2 - 3 } & Aluminium & PVC \\
\hline Corrosion resistance & High & High \\
\hline Electrochemical corrosion risk & Low & Null \\
\hline Vulnerability to thermal bridges & Half & Low \\
\hline $\begin{array}{l}\text { Vulnerability to cuts or } \\
\text { scratches }\end{array}$ & Half & Low \\
\hline $\begin{array}{l}\text { Degradation by saline } \\
\text { environment }\end{array}$ & Half & Null \\
\hline Risk of condensation inside & Low & Null \\
\hline Difficulty cleaning & Low & Low \\
\hline Window weight & Low & High \\
\hline Maintenance & Half & Low \\
\hline
\end{tabular}

Fig .3 Factors influencing both durability and window maintenance.

On the other hand, the acquisition of a window brings with it a subsequent installation. Under this circumstance, the Chilean market generally delivers a price to the buyer that includes the installation value. The latter may vary due to the dimensions of the window and the distance or location of the destination. However, the type of window material does not influence this cost, in other words, that a window made up of one material or another will not increase or decrease the installation value. 
Nevertheless, in the stage of exploitation or use of the window, there are economic differences related to the material composition. Since the durability and maintenance are not the same in all cases, as shown in Fig. 3. For this reason, has been used the two most recurring window compositions, aluminium and PVC, have been used to identify the variables that can influence the maintenance costs, as well also as in the useful life of them [26]. The latter being an essential factor in determining when to make a replacement.

\section{Technical Characteristics}

The methodology explicitly uses the following types of variables; region, commune, thermal zone, facade surface according to orientation, frame material, window type and thermal transmittance (U) [27] [28] [29] [30]. All of these options allow recreating the conditions of the home better. After entering the information, there is an optimal solution for our case through a technical file, which implicitly contains information such as; glass-framed ratio, glass thickness, inner chamber space, the filling inside the chamber, the rail thickness and air permeability [31] [32]. In summary, have to adjust the data at the beginning, to later know in detail the characteristics of windows.

Additionally, a graphic representation of them allows the user to use as a means for the quotation, manufacture, and implementation of the windows. All this information ensures a correct and quick selection of windows for the case in question.

\section{B. Methodology of the Verification Process}

According to Fig. 4, the simulation considers housing in different climatic zones (Antofagasta, Santiago, Concepción) to which improvements are subsequently implemented in its windows. It is important to note that energy demand is calculated based on passive systems and does not include equipment (No HVAC). However, the HAP program [33] was used to simulate housing, which uses ASHRAE Std. 62.1 - 2010 [34], ASHRAE Std. 90.1 - 2010 [35] and LEED 2009 [36] as a regulatory framework.

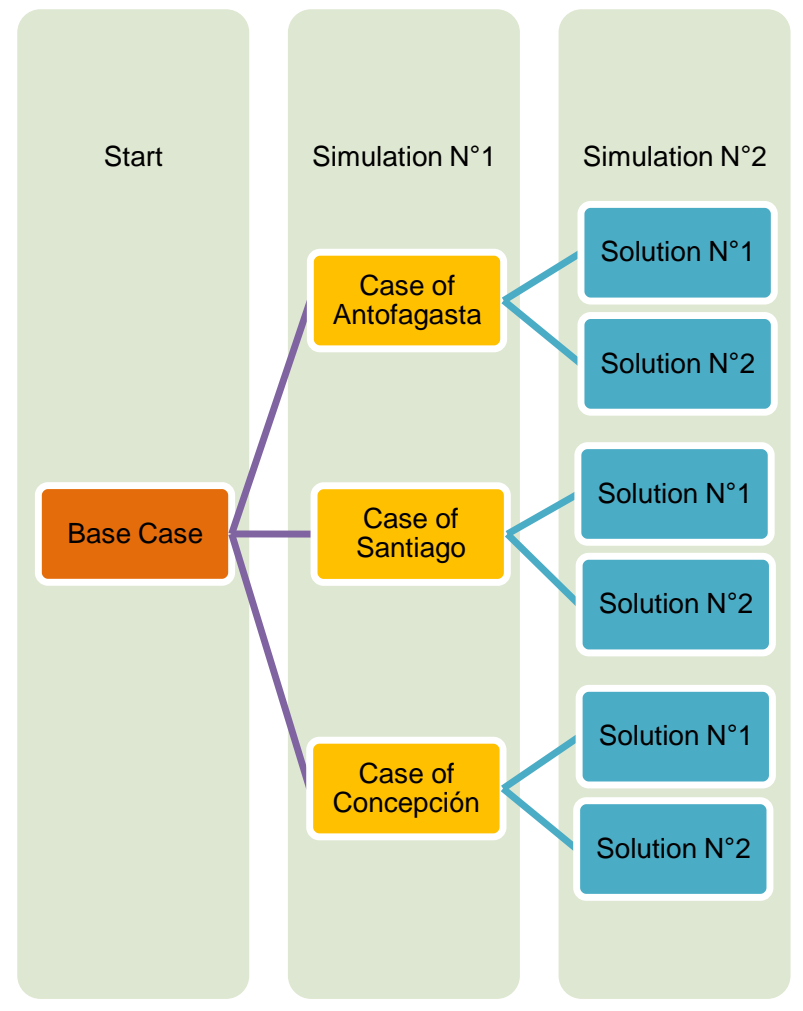

Fig .4 Flowchart to obtain case analysis.

1. Characteristics of Base Cases

The base cases are made up of the technical specifications exemplified in Figs. 5, 6 and 7.

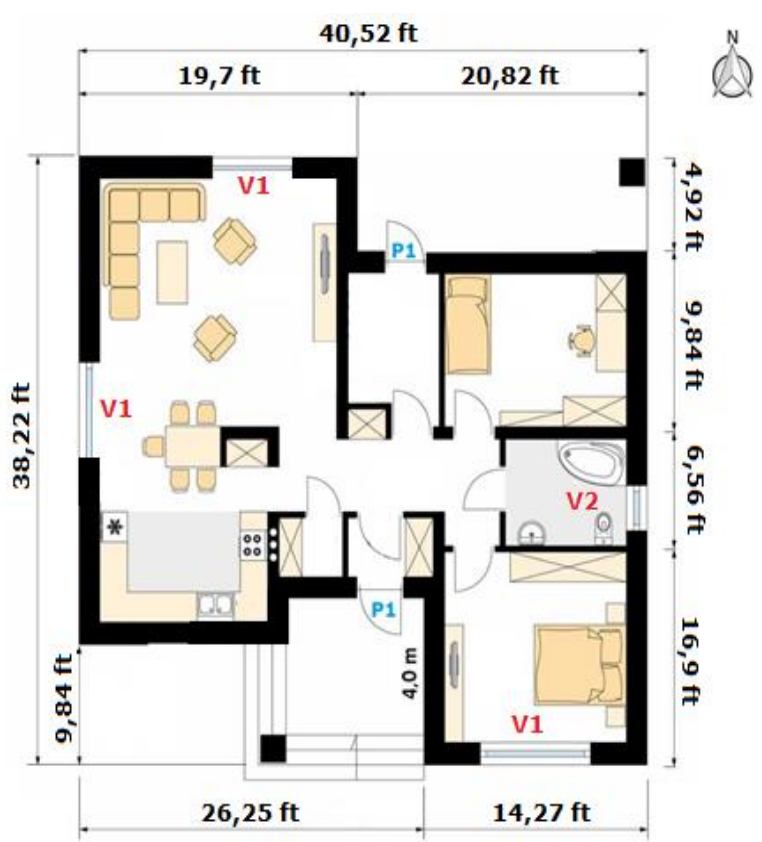

Fig .5 General architecture plant for base cases. 

http://dx.doi.org/10.21622/RESD.2020.06.1.008

\begin{tabular}{|c|c|c|c|c|}
\hline City & Element & High $(\mathrm{ft})$ & Surface (ft2) & $\mathrm{U}(\mathrm{BTU} / \mathrm{hr} / \mathrm{ft} 2 / \mathrm{F})$ \\
\hline \multirow{6}{*}{$\begin{array}{l}\frac{\pi}{0} \\
\mathbb{0} \\
\frac{\pi}{0} \\
\frac{\pi}{0} \\
\frac{0}{1} \\
\frac{1}{4}\end{array}$} & Facade $\mathrm{N}$ & 7,55 & 304,62 & 0,29 \\
\hline & Facade S & 7,55 & 292,78 & 0,29 \\
\hline & Facade $\mathrm{E}$ & 7,55 & 248,65 & 0,29 \\
\hline & Facade W & 7,55 & 249,72 & 0,29 \\
\hline & Roof & - & 1337,95 & 0,06 \\
\hline & Floor & 0,49 & 1145,28 & 0,52 \\
\hline \multirow{6}{*}{ 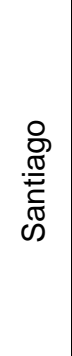 } & Facade $\mathrm{N}$ & 7,55 & 304,62 & 0,29 \\
\hline & Facade S & 7,55 & 292,78 & 0,29 \\
\hline & Facade $\mathrm{E}$ & 7,55 & 248,65 & 0,29 \\
\hline & Facade W & 7,55 & 249,72 & 0,29 \\
\hline & Roof & - & 1337,95 & 0,06 \\
\hline & Floor & 0,49 & 1145,28 & 0,52 \\
\hline \multirow{6}{*}{ 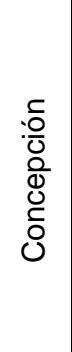 } & Facade $\mathrm{N}$ & 7,55 & 304,62 & 0,29 \\
\hline & Facade S & 7,55 & 292,78 & 0,29 \\
\hline & Facade $\mathrm{E}$ & 7,55 & 248,65 & 0,29 \\
\hline & Facade W & 7,55 & 249,72 & 0,29 \\
\hline & Roof & - & 1337,95 & 0,06 \\
\hline & Floor & 0,49 & 1145,28 & 0,52 \\
\hline
\end{tabular}

\begin{tabular}{|c|c|c|c|c|}
\hline \multirow{2}{*}{ City } & \multicolumn{4}{|c|}{ Solution N¹ } \\
\cline { 2 - 5 } & \multicolumn{4}{|c|}{ Window V1 } \\
\cline { 2 - 5 } & $\begin{array}{c}\text { Frame } \\
\text { Type }\end{array}$ & $\begin{array}{c}\text { Window } \\
\text { opening }\end{array}$ & $\begin{array}{c}\text { Surface } \\
\text { (ft2) }\end{array}$ & $\begin{array}{c}\text { U } \\
(\mathrm{BTU} / \mathrm{hr} / \mathrm{ft} 2 / \mathrm{F})\end{array}$ \\
\hline Antofagasta & Aluminium & $\begin{array}{c}\text { Side- } \\
\text { hung }\end{array}$ & 19,4 & 0,63 \\
\hline Santiago & Aluminium & Sliding & 17,8 & 0,63 \\
\hline Concepción & Aluminium & Sliding & 12,9 & 0,63 \\
\hline
\end{tabular}

Fig .8 Summary of solutions No. 1 to simulate.

\begin{tabular}{|c|c|c|c|c|}
\hline \multirow{2}{*}{ City } & \multicolumn{4}{|c|}{ Solution No2 } \\
\cline { 2 - 5 } & \multicolumn{4}{|c|}{ Window V1 } \\
\cline { 2 - 5 } & $\begin{array}{c}\text { Frame } \\
\text { Type }\end{array}$ & $\begin{array}{c}\text { Window } \\
\text { opening }\end{array}$ & $\begin{array}{c}\text { Surface } \\
\text { (ft2) }\end{array}$ & $\begin{array}{c}\text { U } \\
(\mathrm{BTU} / \mathrm{hr} / \mathrm{ft} 2 / \mathrm{F})\end{array}$ \\
\hline Antofagasta & PVC & Side-hung & 19,4 & 0,53 \\
\hline Santiago & PVC & Sliding & 24,2 & 0,42 \\
\hline Concepción & PVC & Sliding & 12,9 & 0,28 \\
\hline
\end{tabular}

Fig .9 Summary of solutions No. 2 to simulate.

\section{RESULTS}

Fig .6 Structural elements of the base cases.

\begin{tabular}{|c|c|c|c|c|c|}
\hline City & Element & $\begin{array}{l}\text { High } \\
\text { (ft) }\end{array}$ & $\begin{array}{l}\text { Width } \\
(\mathrm{ft})\end{array}$ & $\begin{array}{c}\text { Surface } \\
\text { (ft2) }\end{array}$ & $\begin{array}{c}U \\
(\mathrm{BTU} / \mathrm{hr} / \mathrm{ft} 2 / \mathrm{F})\end{array}$ \\
\hline \multirow{3}{*}{ 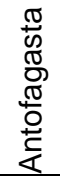 } & P1 & 6,6 & 2,8 & 18,3 & 0.32 \\
\hline & V1 & 5,2 & 5,2 & 27,6 & 1,02 \\
\hline & V2 & 1,6 & 1,6 & 2,7 & 0,53 \\
\hline \multirow{3}{*}{ 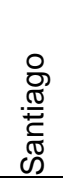 } & $\mathrm{P} 1$ & 6,6 & 2,8 & 18,3 & 0.32 \\
\hline & V1 & 5,2 & 5,2 & 27,6 & 1,02 \\
\hline & V2 & 1,6 & 1,6 & 2,7 & 0,53 \\
\hline \multirow{3}{*}{$\begin{array}{l}: \\
: \frac{0}{0} \\
\frac{0}{0} \\
0 \\
0 \\
0 \\
0\end{array}$} & $\mathrm{P} 1$ & 6,6 & 2,8 & 18,3 & 0.32 \\
\hline & V1 & 5,2 & 5,2 & 27,6 & 1,02 \\
\hline & V2 & 1,6 & 1,6 & 2,7 & 0,53 \\
\hline
\end{tabular}

Fig .7 Non-structural elements of the base cases.

\section{Characteristics of the Solutions to Simulate}

The solutions for the simulations appear from replacing the initial windows $\mathrm{V} 1$ with others with better performance, through the methodology. As a summary of the improvement selection process, Figs. 8 and 9 show all the information necessary to prepare the simulations.

Figure 10 shows the cooling or heating energy required by a window $\mathrm{V} 1$. Indicating that the cities of Antofagasta and Concepción have cooling gains with their negative statistics. This is not the case in Santiago, whose values show an additional demand for it. As for heating, all windows require other energy input. The window that achieved the best performance was the solution $n^{\circ} 2$ in the city of Concepción. Since it has a favourable contribution of cooling energy (- 16 BTU / hr) and its heating demand is the lowest (126 $\mathrm{BTU} / \mathrm{hr}$ ).

Figs 11 and 12 indicate the amount of variation and heating energy required by the total windows of the house in comparison with the total area of these houses. In particular, the heating demand values are much higher than the cooling figures, with a difference between them that ranges $87 \%$ and $93 \%$. On the other hand, the window that obtained better performance in both graphics. Is the S2 solution in the city of Santiago because it has the smallest reduction in surface area, $11 \%$ compared to the base case. Also, it manages to reduce the cooling and heating needs by $64 \%$ concerning its base case. 
Figs 13 and 14 it show the heat that flows per unit of time and surface area $(U)$ in the windows compared to the total demand for cooling or heating energy of the house. The cooling demand values are much higher than those required for heating as there is having a difference between them that ranges between $70 \%$ and $86 \%$. Moreover, the city that presented the most significant energy demands was that of Santiago reaching differences of up to $9 \%$ in cooling and $56 \%$ in heating. However, the city that shows the lowest energy savings is Antofagasta, decreasing only $1.5 \%$ in cooling and having a maximum of $9 \%$ in heating. In comparison, the city that achieved the best energy performance was the city of Concepcion with solution S2 since it managed to reduce cooling energy by $3 \%$ and $12 \%$ for heating.

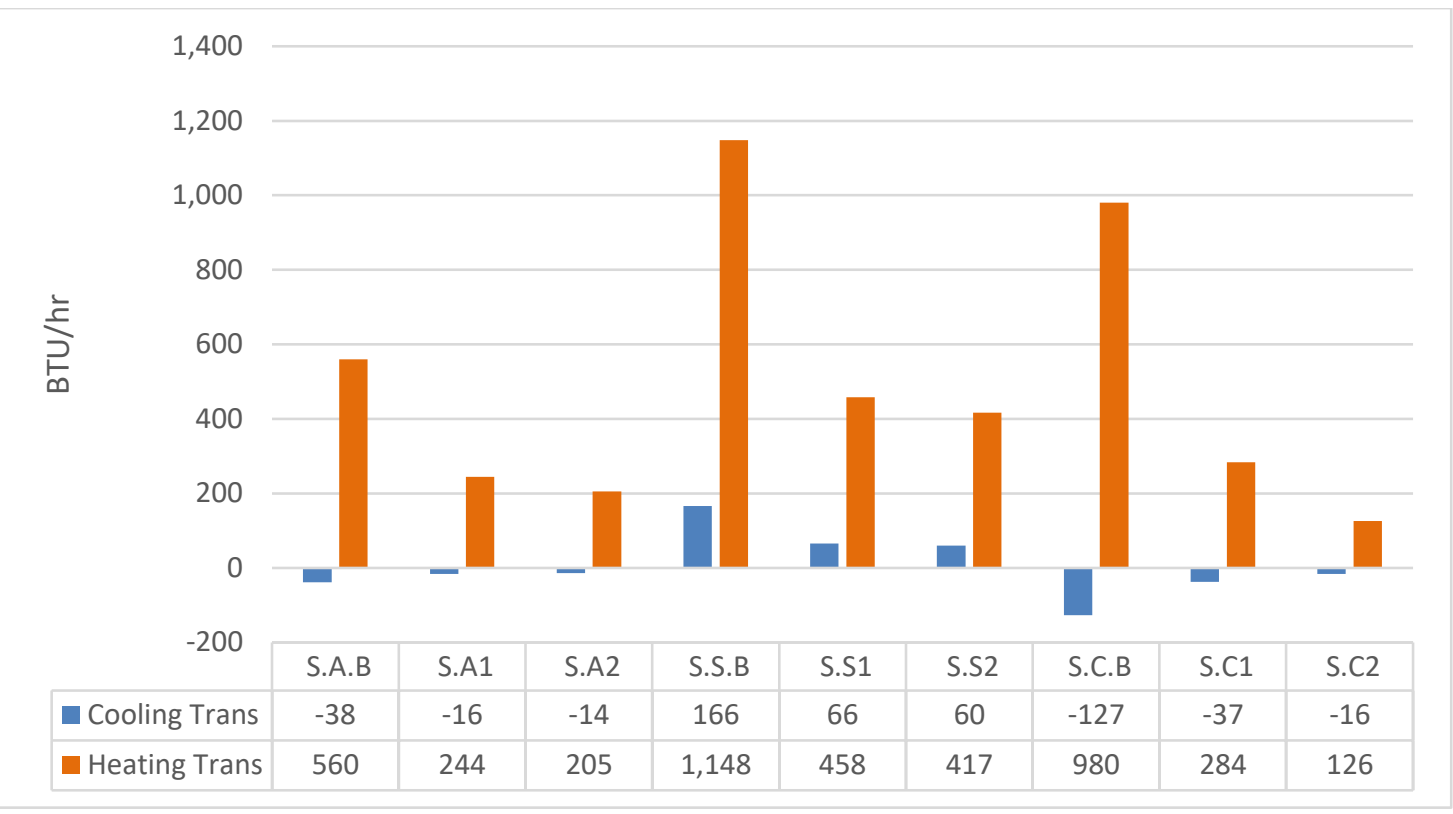

Fig. 10. Cooling vs heating energy required by a V1 window.

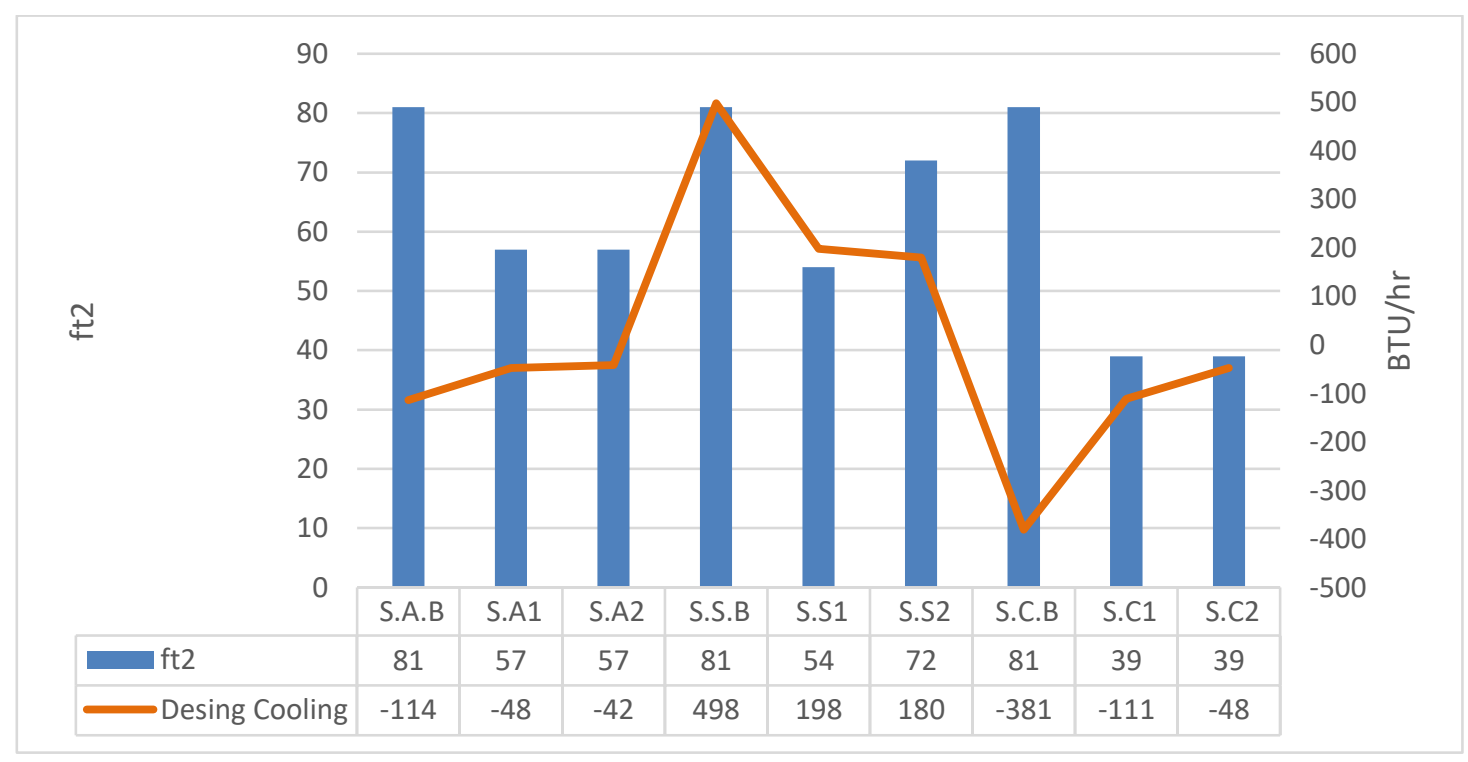

Fig. 11. Total surface of the V1 windows vs energy supply for cooling them. 


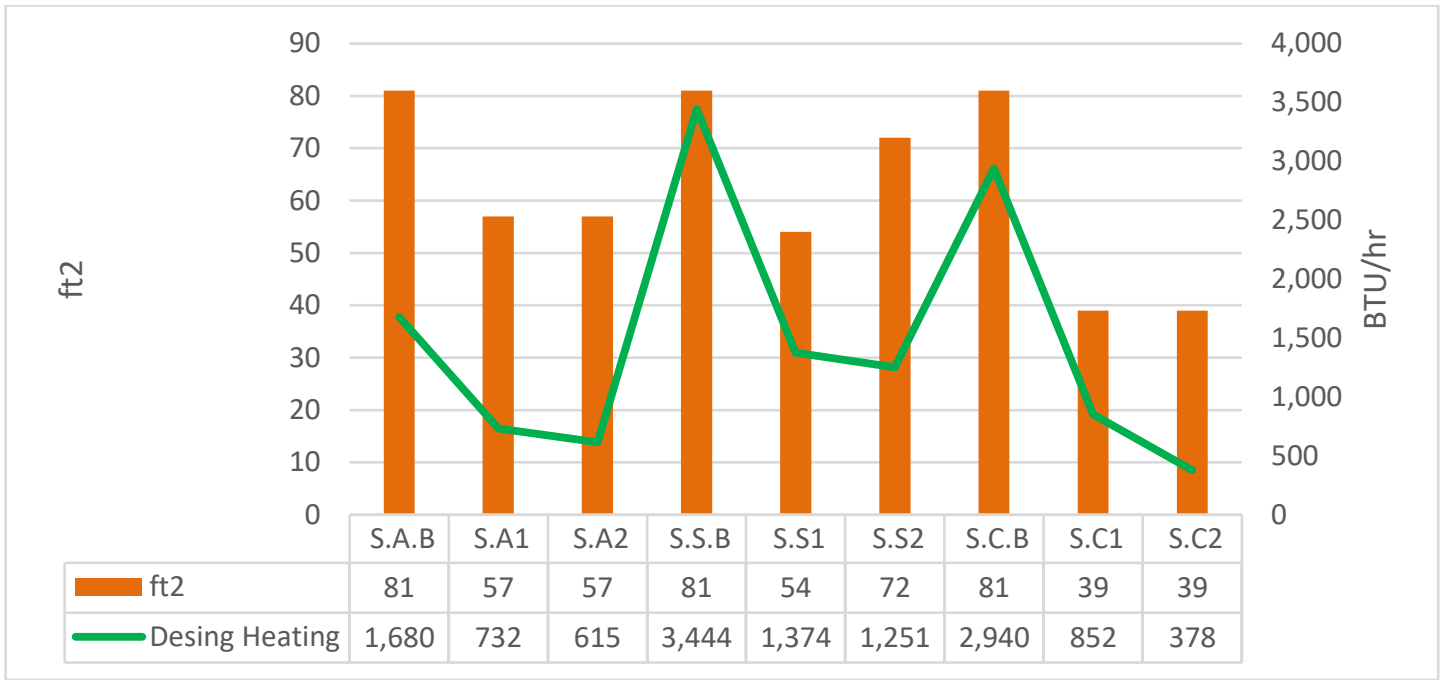

Fig. 12. Total surface of the windows V1 vs energy supply for heating them.

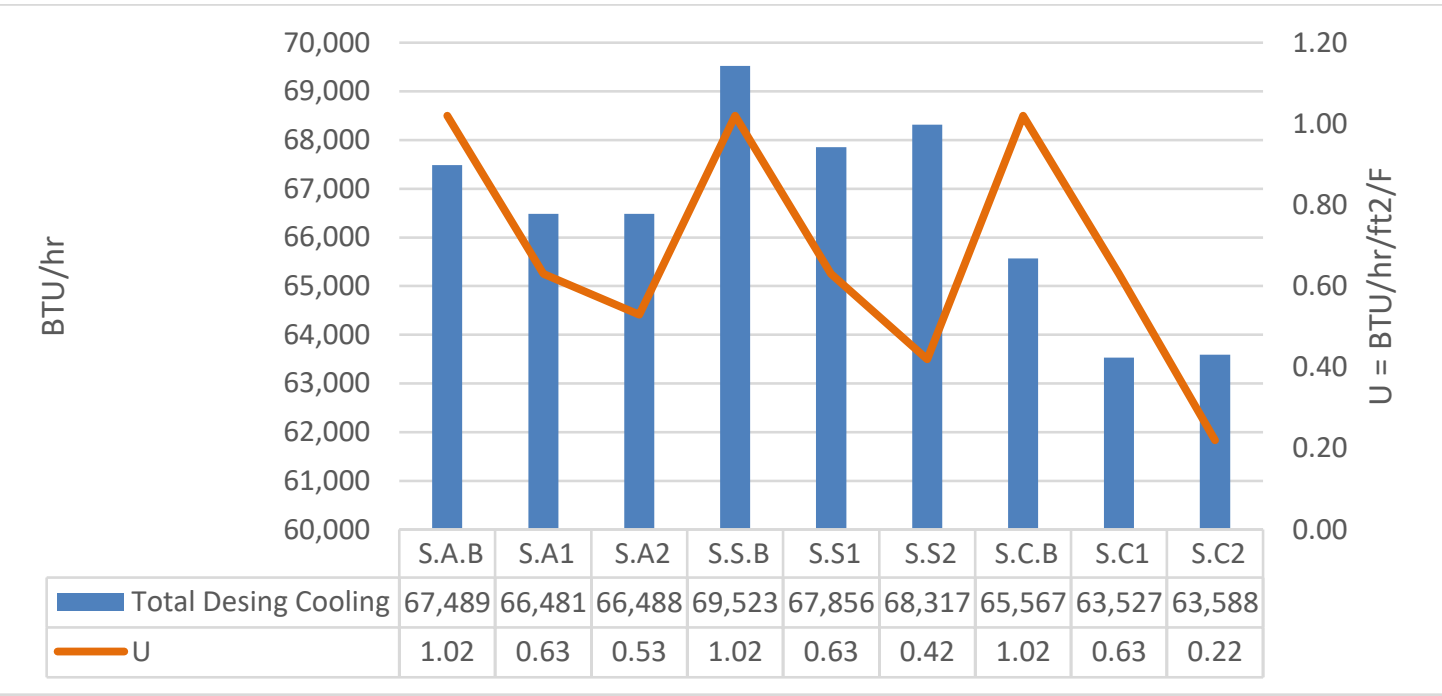

Fig. 13. Thermal transmittance of the window $(U)$ vs total energy demand for cooling.

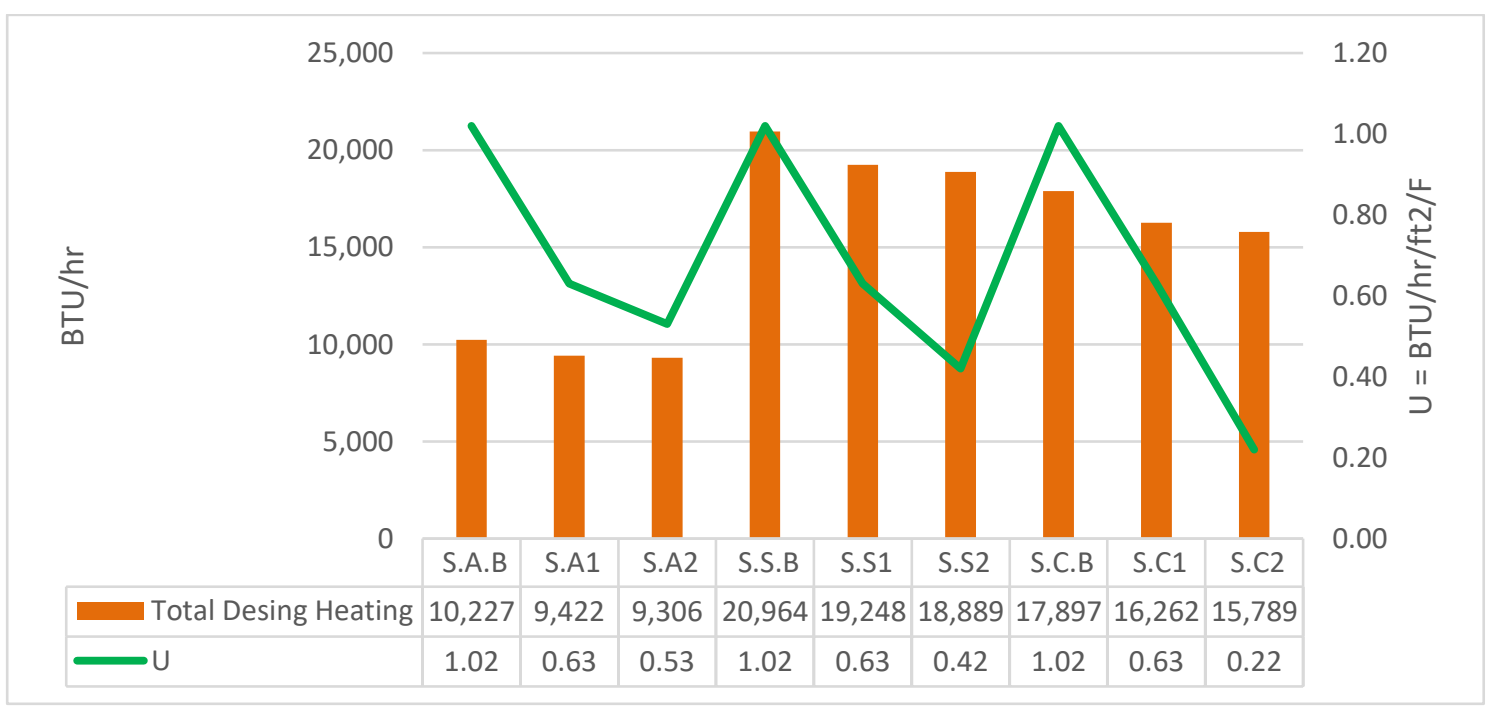

Fig. 14. Thermal transmittance of the window $(U)$ vs total energy demand for heating. 


\section{CONCLUSION}

After evaluating the passive energy performance of homes, it is concluded that the highest energy demands were recorded in cooling and they were much higher than those required for heating. As a result, the double airtight glass allows reducing the solar gain but fails to eliminate overheating in hightemperature seasons.

Other relevant data provided by the simulations correspond to the relationship between the thermal transmittance $(U)$ of the windows and the total energy demand of the house (BTU / hr). Specifically, when using windows with small values of $U$ in geographic areas where high temperatures prevail, great energy and economic performance are not obtained. Radiation control measures are more practical to combat these situations.

In geographical areas where low temperatures are recurrent, the strategy is of using very high-quality windows is not always viable. That is to say, using thermal transmittance values that are very low or close to $1.0 \mathrm{BTU} / \mathrm{hr} / \mathrm{ft} 2$ / F. Together with decreasing their dimensions, they singularly favour the heating demand reduction. However, this situation is not entirely profitable because the natural light surface is lost, and the implementation costs are too high.

In temperate climates, it is where the correct selection of the windows has a higher incidence. Because, if windows with $U$ values ranging between 2.0 and 3.0 $\mathrm{BTU} / \mathrm{hr} / \mathrm{ft} 2$ / F are used, a considerable reduction in the energy demands of the house is obtained, with a reasonable implementation cost. For example, in cold months, the solar radiation decreases, allowing the double airtight glass to limit heat transfers between the interior and exterior of homes in addition to avoiding condensation in the interior glass.

In contrast, in months of high temperatures, the same windows allow cooling through cross ventilation caused by opening them. In the case of having a ventilation, heating and air conditioning system (HVAC) the windows with the indicated characteristics allow encapsulating or retaining the comfortable temperature inside the enclosure, avoiding energy loss.

In general, it is confirmed that windows with lower thermal transmittance $(U)$ achieve better energy performance in homes. However, the selection of optimal windows for a project should always be based on the geographical area, the orientation of the facade or wall, the surface of light or visibility to be projected (dimensions) and the values of thermal transmittance (U). For example, the simulations showed that the S2 solution obtained a better performance of energy efficiency in the three cities mainly because it had $U$ figures and slightly smaller surfaces than the $S 1$ option.

As for the users of homes in Chile and around the world, the following inferred; usually, they do not know the energy demand of homes, much less about the selection of doors or windows with excellent performance. Because these responsibilities transferred to government authorities, this means that it is the governments that generate the energy efficiency and sustainability strategies, according to the political, social and economic reality that they live. However, the difference is that Europe, unlike Chile, has more experience and track record on this issue. Instead, Chile is in the process of transition, since its policies and regulations are recent or in the development stage.

About the above and the evidence collected, it is possible to affirm that this methodology can effectively provide support to users, allowing them to know when it is profitable to change their windows for one that has a better performance. On the other hand, the implementation of this in the design stage allows knowing the cost and benefit relationship that exists between the windows, a critical factor in projects where resources are minimal, such as social projects. Furthermore, it favours the country's energy transition process in a transversal manner. In other words, it involves all the stages of a project; design, construction, operation and demolition or replacement in this case. It can be implemented free of charge, with high possibilities of application in the market and with national coverage. However, the successful integration of this in the field depends on the improvement of the current legal and technical framework that surrounds it, a modest initial investment, additionally a process of information and standardization of the market.

\section{ACKNOWLEDGMENTS}

Dr. David Blanco and Danny Lobos supervised this research at Universidad Tecnológica Metropolitana de 
Chile under a master's project from the School of Engineering.

\section{REFERENCES}

[1] OECD and United Nations Economic Commission for Latin America and the Caribbean, "OECD Environmental Performance Reviews: Chile 2016", Secretary-General of the OECD, Paris, 2016.

[2] APEC Chile 2019, "APEC Chile 2019", 2019, available on: https://www.apecchile2019.cl/apec/acerca-deapec/about-apec.

[3] Ministerio del Medio Ambiente de Chile, "Ministerio del Medio Ambiente", 2012, available on: $\quad$ https://sinia.mma.gob.cl/temasambientales/compromisos-internacionales/.

[4] EU Parliament, Directive 2010/ 31/EU, EU Parliament, 2010.

[5] Comisión Nacional de Energía Chile, "Anuario estadístico de energía 2018," Ministerio de Energía, Santiago, 2018.

[6] Comisión Nacional de Energía Chile, "Energía Abierta", 2018, available on: http://datos.energiaabierta.cl/dataviews/253790/ balance-energetico-2018/.

[7] Ministerio de Energía de Chile, "Estrategia nacional de energía 2012-2030", Santiago, 2012.

[8] Ministerio de Energía de Chile, "Plan de Acción de Eficiencia Energética 2020", Santiago, 2013.

[9] Ministerio de economía, fomento y reconstrucción de Chile, Política energética, Ley $N \circ 20.257$, Santiago, 2013.

[10] Ministerio de Vivienda y Urbanismo. Gobierno de Chile, Estándares de Construcción Sustentable para Viviendas, Tomo II: Energía, Santiago: División Técnica de Estudio y Fomento Habitacional - Ditec, Minvu, 2018.
[11] Ministerio de Vivienda y Urbanismo. Gobierno de Chile, Estándares de Construcción Sustentable para Viviendas, Tomo III: Agua, Santiago: División Técnica de Estudio y Fomento Habitacional - Ditec, Minvu, 2018.

[12] Ministerio de Vivienda y Urbanismo. Gobierno de Chile, Estándares de Construcción Sustentable para Viviendas, Tomo IV: Materiales y Residuos, Santiago: División Técnica de Estudio y Fomento Habitacional - Ditec, Minvu, 2018.

[13] Ministerio de Vivienda y Urbanismo. Gobierno de Chile, Vol. 2 Manual de Procedimientos Calificación Energética de Viviendas en Chile, Santiago: División Técnica de Estudio y Fomento Habitacional - Ditec, Minvu, 2019.

[14] Ministerio de Vivienda y Urbanismo. Gobierno de Chile, Ley general de Urbanismo y Construcciones, Santiago, 1975.

[15] Ministerio de Vivienda y Urbanismo. Gobierno de Chile, Ordenanza General de la Ley General de Urbanismo y Construcciones., Santiago, 1992.

[16] Ministerio de Vivienda y Urbanismo. Gobierno de Chile, Manual de Aplicación de la Reglamentación Térmica, Santiago, 2007.

[17] Ministerio del Medio Ambiente Gobierno de Chile, "Ministerio del Medio Ambiente - Planes de Descontaminación Atmosférica Estrategia 20142018", 2014, available on: https://mma.gob.cl/planes-dedescontaminacion-atmosferica-estrategia-20142018/.

[18] Ministerio de Vivienda y Urbanismo. Gobierno de Chile, "MINVU - Planes de Descontaminación Atmosférica", 2017, available on: https://www.minvu.cl/planes-dedescontaminacion-atmosferica/.

[19] Centro del Ciencia del Clima y Resiliencia (CR)2, "Explorador Climático (CR)2", Meteodata, 2017, available on: http://explorador.cr2.cl/. 
[20] Ministerio de Vivienda y Urbanismo. Gobierno de Chile, "Instrucciones de Informar a DOM de comunas con PDA sobre Exigencias de Aisalación Térmica de Sobrecimiento y Ventanas en Viviendas Nuevas", 2018, available on: https://f7b235ff-bd9f-430d-b656-

612f8b4c3881.filesusr.com/ugd/2f1e74 c54089 853e234e759fbc0c5a4dd8d239.pdf.

[21] Ministerio de Vivienda y Urbanismo. Gobierno de Chile, "Plan descontaminación atmosférica Osorno", 2018, available on: https://www.pdao.cl/copia-de-documentos.

[22] Catálogo Arquitectura, "Catálogo Arquitectura", 2017, available on: https://www.catalogoarquitectura.cl/cl/nosotros.

[23] Camara Chilena de Construcción, "Informe Macroecomía y Construcción 2017", Camara Chilena de Construcción, Santiago, 2017.

[24] Camara Chilena de Construcción, "Informe Macroeconoía y Construcción", Camara Chilena de Construcción, Santiago, 2019.

[25] DITEC, "Estándares Técnicos para proyectos de Acondicionamiento Térmico (AT) en Condominios de Viviendas Sociales.", División Técnica del MINVU (DITEC), Santiago, 2018.

[26] Clavelocal, "Clavelocal.com", 2015, available on: https://clavelocal.com/ventajas-e-

inconvenientes-de-las-ventanas-de-pvc-yaluminio/.

[27] Instituto Nacional de Normalización, NCh 3137/1 - Comportamiento térmico de ventanas, puertas y contraventanas - Cálculo de transmitancia térmica - Parte 1: Generalidades., Santiago: Instituto Nacional de Normalización, 2008.

[28] Instituto Nacional de Normalización, NCh $3137 / 2$ - Comportamiento térmico de ventanas, puertas y contraventanas - Cálculo de transmitancia térmica - Parte 2: Método numérico para marcos., Santiago: Instituto Nacional de Normalización, 2008.
[29] Instituto Nacional de Normalización, NCh 3076/1 - Comportamiento térmico de puertas y ventanas - Determinación de la transmitancia térmica por el método de la cámara térmica - Parte 1: Puertas y ventanas., Santiago: Instituto Nacional de Normalización, 2008.

[30] Instituto Nacional de Normalización, Nch 3076/2 - Comportamiento térmico de puertas y ventanas - Determinación de la transmitancia térmica por el método de la cámara térmica - Parte 2: Ventanas de techumbres y otras ventanas sobresalientes., Santiago: Instituto Nacional de Normalización, 2008.

[31] Instituto Nacional de Normalización, NCh3297 Puertas y ventanas - Permeabilidad al aire Método de ensayo., Santiago: Instituto Nacional de Normalización, 2013.

[32] Instituto Nacional de Normalización, NCh3296 Puertas y ventanas - Permeabilidad al aire Clasificación., Santiago: Instituto Nacional de Normalización, 2013.

[33] Carrier, "Carrier", 2018, available on: https://www.carrier.com/commercial/en/us/softw are/hvac-system-design/hourly-analysisprogram/.

[34] American Society of Heating, Refrigerating and Air-Conditioning Engineers (ASHRAE), ASHRAE Std. 62.1, Atlanta: ASHRAE, 2010.

[35] American Society of Heating, Refrigerating and Air-Conditioning Engineers (ASHRAE), ASHRAE Std. 90.1, Atlanta: ASHRAE, 2010.

[36] Green Building Council (GBCI), LEED Reference Guide for Green Building Design \& and Construction, Washington, DC: Green Building Council (GBCl), 2009.

[37] G. P. F. C. P. R. P. Andrea Gasparellaa, "Analysis and modelling of window and glazing systems energy performance for a well insulated residential building," Energy and Buildings, 43 (4), pp. 1030-1037, 2011. 
[38] O. Aydın, "Conjugate heat transfer analysis of double pane windows," Building and Environment, 41 (2), pp. 109-116, 2006.

[39] B. M. M. S. U. Larsson ab, "Thermal analysis of super insulated windows (numerical and experimental investigations)," Energy and Buildings, 29 (2), pp. 121-128, 1999.

[40] N. P. Parham Sadooghia, "Thermal analysis of triple and quadruple windows using partitioning radiant energy veils ${ }^{\mathrm{TM}}$ with different physical and optical properties," Solar Energy,174 (109), ISSN 0038-092X, pp. 1163-1168, 2018.

[41] E. R. A. R. G. Á. Ana Rita Amarala, "A thermal performance parametric study of window type, orientation, size and shadowing effect," Sustainable Cities and Society, 26 (37). ISSN 2210-6707, pp. 456-465, 2011.

[42] A. A. Castaño, WIND SEAL - Distribuidora de perfiles de aluminio, Santiago: Universidad de Chile, 2015. 